Provided for non-commercial research and education use. Not for reproduction, distribution or commercial use.

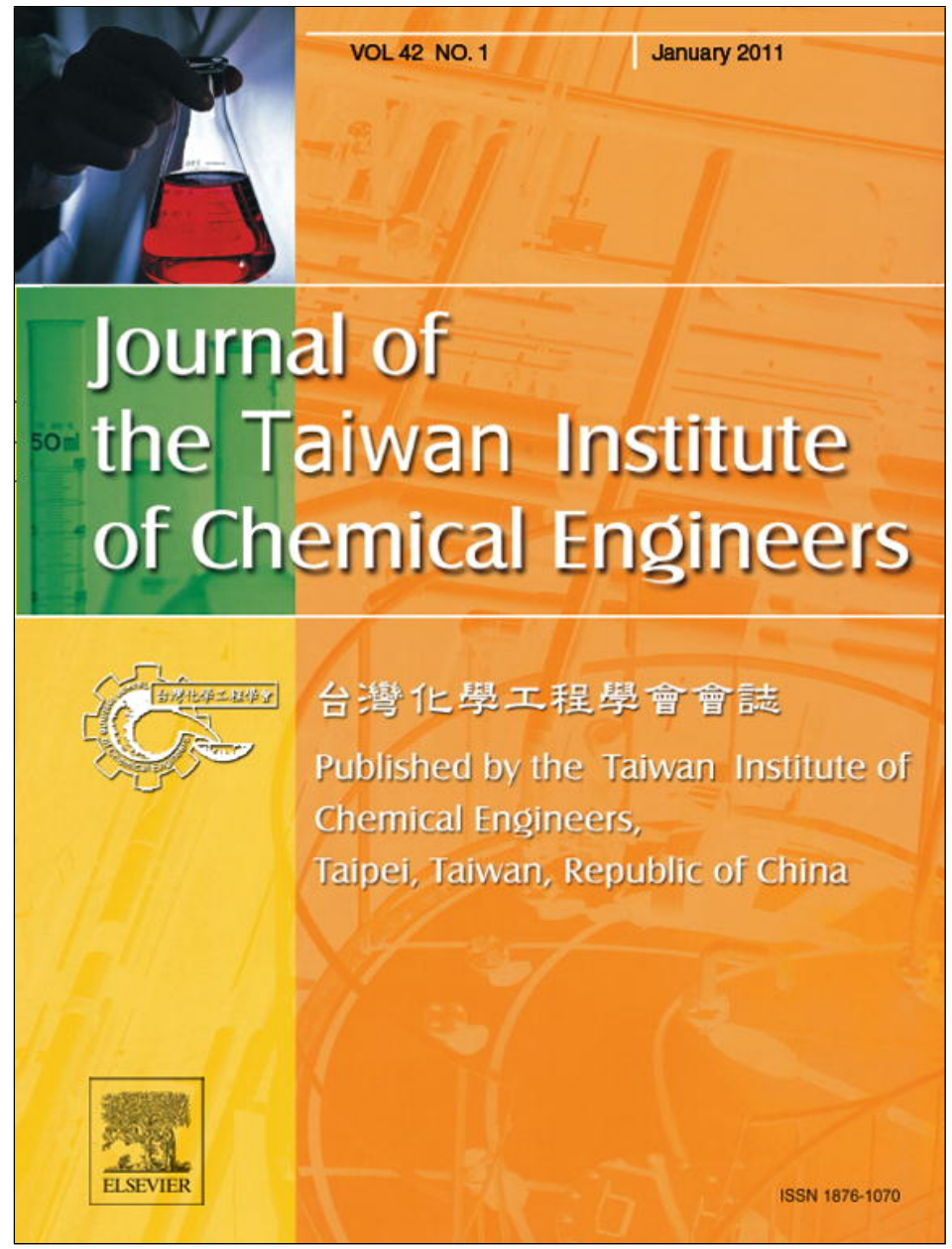

This article appeared in a journal published by Elsevier. The attached copy is furnished to the author for internal non-commercial research and education use, including for instruction at the authors institution and sharing with colleagues.

Other uses, including reproduction and distribution, or selling or licensing copies, or posting to personal, institutional or third party websites are prohibited.

In most cases authors are permitted to post their version of the article (e.g. in Word or Tex form) to their personal website or institutional repository. Authors requiring further information regarding Elsevier's archiving and manuscript policies are encouraged to visit:

http://www.elsevier.com/copyright 


\title{
Isolation and characterization of starch from defatted rice bran
}

\author{
Cynthia Fabian $^{\text {a }}$, Aning Ayucitra ${ }^{\text {b }}$, Suryadi Ismadji ${ }^{\text {, }}$, Yi-Hsu Ju ${ }^{\text {a,* }}$ \\ a Department of Chemical Engineering, National Taiwan University of Science and Technology, Taipei 10607, Taiwan \\ ${ }^{\mathrm{b}}$ Department of Chemical Engineering, Widya Mandala Surabaya Catholic University, Kalijudan 37, Surabaya 60114, Indonesia
}

\section{A R T I C L E I N F O}

\section{Article history:}

Received 19 August 2009

Received in revised form 5 February 2010

Accepted 7 March 2010

\section{Keywords:}

Gelatinization

Starch

Rice bran

Thermogravimetric analysis

\begin{abstract}
A B S T R A C T
Rice starch is one of the most expensive yet very useful starches due to its unique characteristics. This study aimed to isolate starch from defatted rice bran, an underutilized byproduct of milling and is a relatively inexpensive source of rice starch. Starch was extracted from the bran by first soaking it in water. The mixture was then subjected to blending and washing with water, alcohol and alkali solution. About $83 \%$ of the rice bran starch was recovered. Characterization of the rice bran starch showed that its gelatinization and retrogradation properties as well as its granule size are similar to those of starch from rice endosperm. Based on the results of this study, defatted rice bran can be a good source of starch that is suitable for applications in food and pharmaceutical industry and other new applications such as a potential material in the biomedical field.
\end{abstract}

(c) 2010 Taiwan Institute of Chemical Engineers. Published by Elsevier B.V. All rights reserved.

\section{Introduction}

Starch serves as the major reserve of polysaccharide in plants that provides the bulk nutrient and energy source in human diet (Galliard, 1987; Shelton and Lee, 2000). It finds wide applications not only in food but also in pharmaceutical and biomedical industries because of its biocompatibility, biodegradability, nontoxicity, and abundant sources (Kaur et al., 2007).

One of the most interesting applications of starch is in the biomedical field. Starch has been recognized as a potential material in tissue engineering of bone, bone fixation, carrier for the controlled release of drugs and hormones, and as hydrogels (Chakraborty et al., 2004; Lenaerts et al., 1998; Mano and Reis, 2004; Pal et al., 2006; Pereira et al., 1998; Won et al., 1996). Biodegradable bone cements made from starch are highly advantageous because they can provide for immediate structural support and, as they degrade at the site of application, allow the ingrowth of new bone for complete healing of bone fracture (Domb et al., 1996; Pereira et al., 1998). Nanoparticles, nanospheres, and nanogels from starch have also been used as base materials for nanoscale construction of sensors, tissues, mechanical devices, and drug delivery systems (Chakraborty et al., 2004).

From rice starch, a patented process for the production of starch nanoparticles by extrusion method has been described by Giezen et al. (2004). They claimed that the nanoparticles produced can be used as a matrix material like resin materials in coating application, as a thickener, as a fat replacer and as carrier of

\footnotetext{
* Corresponding author. Tel.: +88622737 6612; fax: +886227376644

E-mail address: yhju@mail.ntust.edu.tw (Y.-H. Ju).
}

colorants, medicaments, flavors and other compounds such as drugs that require slow-release agent.

Rice starch is advantageous for nanotechnology applications and other special applications because among plant starch, it has the smallest and narrowest size range of about 2-10 $\mu \mathrm{m}$ (Dendy and Dobraszczyk, 2001). Its contaminating protein is generally considered to be hypoallergenic since there have been no reports related to the occurrence of allergic reactions after eating rice (Helm and Burks, 1996). However, according to Matsuda et al. (1988), a 16-kDa allergenic protein in rice is present but can be decreased or totally removed by enzymatic decomposition as reported by Ito et al. (2005) and Watanabe et al. (1990).

Despite the known unique properties and impressive potential applications of rice starch, it is still not widely used because of its relatively high price compared to other cereal starches and because the co-products of these other grains are currently more valuable than those from rice (Bao and Bergman, 2004; Dendy and Dobraszczyk, 2001). Thus, the possibility of extracting rice starch from cheaper sources would be advantageous.

One source of relatively inexpensive rice starch is rice bran, an underutilized byproduct of rice milling. Rice bran is usually not consumed as food because of its high fiber content and possible hull contamination (Luh, 1991). It also has limited food application because of the rapid development of rancidity due to the activation of lipase in bran upon milling that breaks down glycerides into fatty acids (Juliano, 1985). Development of stabilization techniques has led to the use of a small percentage of rice bran as commercial food products. However, most rice bran is either used directly as an ingredient in animal feed or as fuel in boiler. Rice bran is an undervalued byproduct of rice milling and is rich in carbohydrates, protein, lipids, dietary fibers, vitamins and minerals(Saunders, 1990). 
Rice bran contains high amount of carbohydrates. According to Luh (1991), starch which occurs abundantly only in the endosperm has been identified in the germ and aleurone layers that is part of rice bran. Commercial bran thus contains a fair amount of starch and the value can range from 10 to 55\% depending on the type of milling and amounts of endosperm present (Saunders, 1990).

Mihara et al. (1974) isolated a starch-rich fraction from full-fat rice bran with similar properties to rice starch. However, the properties and composition of the starch they obtained were not reported. Also, there is no report on starch extraction from defatted rice bran. Thus, in this study, starch is isolated from defatted rice bran. Furthermore, the obtained rice bran starch was characterized to provide information for its possible application.

This study is also part of our efforts in developing a method for the total utilization of defatted rice bran. Complete utilization of defatted rice bran would play an important role in lowering the total cost of biodiesel production if rice bran oil is used as the raw material.

\section{Materials and methods}

\subsection{Materials}

Rice bran fresh from milling was purchased from a local rice mill in Taoyuan County, Taiwan. The bran is not specifically from one variety of rice but is a mixture of rice harvested in northern Taiwan. Bran collected from the mill was stored at $-60{ }^{\circ} \mathrm{C}$ before use. Defatting of rice bran was done using hexane in a Soxhlet extractor at $60^{\circ} \mathrm{C}$ for $4 \mathrm{~h}$.

Standards for amylopectin from maize and amylose from potato starch were purchased from Sigma-Aldrich (St. Louis, MO). Enzymes for starch analysis such as amylase and glucoamylase were also obtained from Sigma-Aldrich. All other chemicals used were of reagent grade and were also supplied by the said company.

\subsection{Preparation of rice bran starch}

The isolation of starch from rice bran is shown in Fig. 1. About $10 \mathrm{~g}$ rice bran was soaked in $50 \mathrm{~mL}$ water for $3 \mathrm{~h}$. The mixture was blended in a Philips blender for 5 min. A 60-mesh screen attached

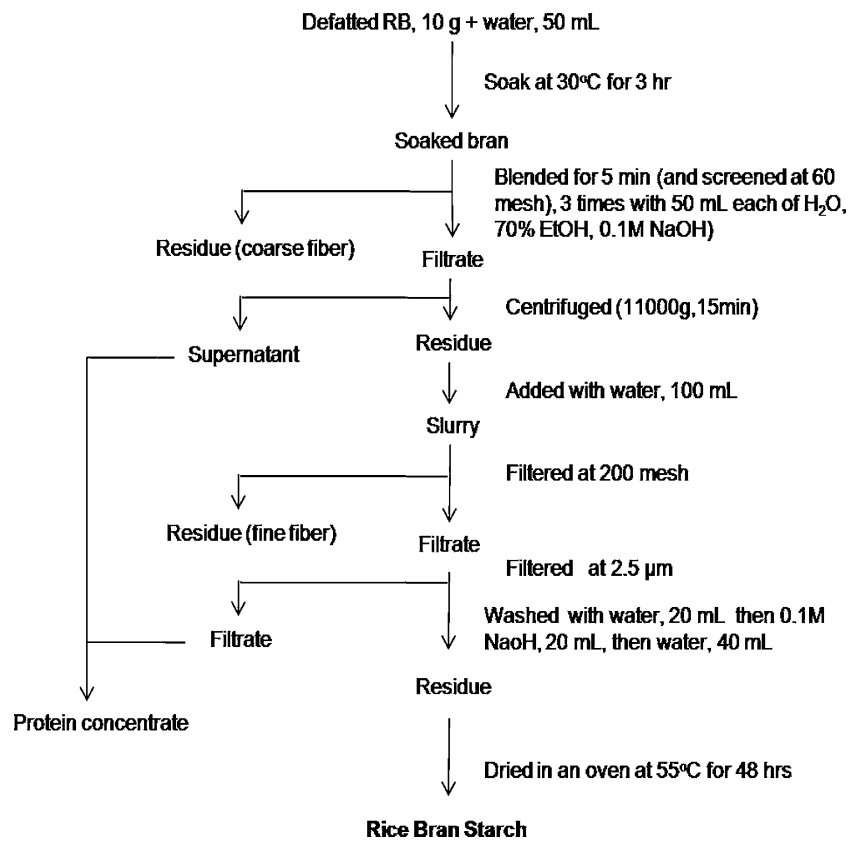

Fig. 1. Wet-milling method for the isolation of starch from rice bran. in the blender aided the separation of the extract from the bran when the extract was poured out of the blender. The bran was then blended again with $70 \%$ ethanol and $0.1 \mathrm{M} \mathrm{NaOH}$ for 5 min for each solvent. The filtrate was centrifuged at $11,000 \times g$ for $15 \mathrm{~min}$. The supernatant was then carefully separated from the solid residue. The residue was reslurried, washed with deionized water and filtered through a 200-mesh screen. The filtrate was filtered again by using a $2.5-\mu \mathrm{m}$ filter paper (Whatman Grade No. 5) and successively washed with $0.1 \mathrm{M} \mathrm{NaOH}$ and deionized water. The residue collected on the filter paper was dried at $55{ }^{\circ} \mathrm{C}$ for $48 \mathrm{~h}$. The dried starch was ground with mortar and pestle and stored in a plastic jar at room temperature for later analyses. All extraction experiments and subsequent analyses were carried out at least twice.

\subsection{Starch product analysis}

\subsubsection{Total starch}

Analysis for total starch extracted was accomplished by using the enzymatic method of Sachez-Castillo et al. (2000) with slight modification. About $0.25 \mathrm{~g}$ of the dried starch product was dispersed in $40 \mathrm{~mL}$ sodium acetate buffer $(0.2 \mathrm{M}, \mathrm{pH} 5.0)$ in a $60-\mathrm{mL}$ glass vial. One hundred microliters of thermostable $\alpha$ amylase (Termamyl 300L, Trump Chemical Corp., Taiwan) was added and the vial was heated in a boiling water bath for $30 \mathrm{~min}$ with constant stirring. The tube was then transferred to a $55{ }^{\circ} \mathrm{C}$ water bath and allowed to equilibrate. About $0.5 \mathrm{~mL} 0.2 \%, \mathrm{w} / \mathrm{v}$, solution of amyloglucosidase $(67.4 \mathrm{U} / \mathrm{mg}$ ) was added. Then, the tube contents were mixed and incubated for about $16 \mathrm{~h}$. The hydrolyzed sample was filtered, transferred to a volumetric flasks and added with deionized water to a final volume of $50 \mathrm{~mL}$.

About $3 \mathrm{~mL}$ of the hydrolyzed sample was placed in a $5-\mathrm{mL}$ tube. Then, $1 \%$ DNS solution was added. The mixture was heated at $90{ }^{\circ} \mathrm{C}$ until its color turned to brownish yellow. After heating, $1 \mathrm{~mL}$ of $40 \%$ Rochelle salt solution was added. The mixture was cooled to room temperature before its glucose content was analyzed using a Jasco UV-vis spectrophotometer (UV-V 550) at $540 \mathrm{~nm}$. The starch content was then calculated by multiplying 0.9 on the glucose content determined (Aman and Hesselman, 1984).

\subsubsection{Amylose content}

The blue value method was used in the determination of amylose content of rice bran starch (Singh et al., 2000). About $0.5 \mathrm{mg}$ starch was placed in a volumetric flask containing $1 \mathrm{~mL}$ ethanol and $2.7 \mathrm{~mL} \mathrm{NaOH}(1 \mathrm{M})$. The mixture was heated at $175^{\circ} \mathrm{C}$ for $15 \mathrm{~min}$, cooled and diluted with deionized water to a total volume of $25 \mathrm{~mL}$. About $2.5 \mathrm{~mL}$ aliquot of the sample was taken and mixed with $2 \mathrm{~mL}$ citric acid $(0.15 \mathrm{M}), 1 \mathrm{~mL}$ iodine solution $\left(0.2 \mathrm{~g} \mathrm{I}_{2}, 2 \mathrm{~g} \mathrm{KI}\right.$ and $250 \mathrm{~mL}$ water) and $14.5 \mathrm{~mL}$ deionized water. The mixture was stored for $20 \mathrm{~min}$ before being analyzed using a Jasco UV-vis spectrophotometer (UV-V 550) at $620 \mathrm{~nm}$.

\subsubsection{Total dietary fiber}

The method of Prosky et al. (1988) was employed for the determination of total dietary fiber (TDF). About $0.25 \mathrm{~g}$ rice bran starch was treated with three enzymes. Firstly, the starch was digested with $0.1 \mathrm{~mL}$ thermostable $\alpha$-amylase at $\mathrm{pH} 6$ for $30 \mathrm{~min}$ in a boiling water bath. The $\mathrm{pH}$ of the mixture was adjusted to 7.5 and $0.01 \mathrm{~g}$ of protease $(16 \mathrm{U} / \mathrm{g}$ ) was added. The mixture was incubated for $30 \mathrm{~min}$ at $60{ }^{\circ} \mathrm{C}$. Lastly, $\mathrm{pH}$ of the mixture was adjusted to 4.5 and amyloglucosidase was added followed by incubation for another $30 \mathrm{~min}$ at $60{ }^{\circ} \mathrm{C}$. Then, $250 \mathrm{~mL}$ preheated $95 \%$ ethanol was added to the mixture and the solution was allowed to precipitate at room temperature for $60 \mathrm{~min}$. The mixture was then filtered using an ashless filter paper (Advantec No. 5C) and the residue was successively washed with $78 \%$ ethanol, $95 \%$ ethanol and acetone. Also, the ash and protein contents of the residue were analyzed by 
AOCS standard methods. Then, the TDF content was determined as the weight of residue less its ash and protein content.

\subsubsection{Swelling and solubility}

Swelling and solubility of rice bran starch were studied using the methods of Singh et al. (2000). About $500 \mathrm{mg}$ starch was added in $20 \mathrm{~mL}$ water and the solution was heated at various temperatures $\left(30-90^{\circ} \mathrm{C}\right)$ for $30 \mathrm{~min}$. The mixture was weighed and water was added to make the total weight equal to $25 \mathrm{~g}$. The weighed mixture was then centrifuged and the supernatant was decanted. The residue was weighed for the determination of swelling power by using the following formula (Singh et al., 2000): Swelling power $=$ wet residue weight $(\mathrm{g}) / 500$

$$
\text { - dried starch weight }(\mathrm{g})
$$

For starch solubility determination, about $10 \mathrm{~mL}$ supernatant obtained from the centrifugation of the starch solution was dried at $105{ }^{\circ} \mathrm{C}$ for $3 \mathrm{~h}$ and then weighed. The solubility was calculated using the following formula (Singh et al., 2000):

Solubility $=$ dry residue weight $(\mathrm{g}) \times 2.5$

$$
\times 100 / \text { starch weight }(\mathrm{g})
$$

\subsubsection{Thermal analysis}

Thermal properties of rice bran starch were analyzed using a DSC Jade (Perkin Elmer) and the methods were based from the study of Singh Sodhi and Singh (2003). About $3.5 \mathrm{mg}$ rice bran starch was weighed and put in a $40-\mu \mathrm{L}$ aluminum pan (TA Instruments, USA). Distilled water was added to achieve a starchwater suspension containing $70 \%$ water. The sample was sealed and allowed to stand for $1 \mathrm{~h}$ at room temperature before heating in the DSC. The DSC was calibrated using indium and an empty aluminum pan was used as the reference. Sample pans were heated from 25 to $100{ }^{\circ} \mathrm{C}$ at $10^{\circ} \mathrm{C} / \mathrm{min}$. Onset temperature $\left(T_{\mathrm{o}}\right)$, peak temperature $\left(T_{\mathrm{p}}\right)$ and enthalpy of gelatinization $\left(\Delta H_{\text {gel }}\right)$ were calculated automatically using the Pyris thermal data analysis software.

After cooling the sample was stored at $4{ }^{\circ} \mathrm{C}$ for 7 days. Retrogradation was measured by reheating the sample pan containing rice bran starch from 25 to $100^{\circ} \mathrm{C}$ at $10^{\circ} \mathrm{C} / \mathrm{min}$. The enthalpy of retrogradation $\left(\Delta H_{\text {ret }}\right)$ was calculated automatically and the percentage of retrogradation (\%R) was calculated as follows (White et al., 1989):

$\% R=\frac{\Delta H_{\text {ret }}}{\Delta H_{\text {gel }}}$

A Perkin Elmer Diamond TG/DTA Instrument (Perkin Elmer, Japan) was used for thermal stability studies. Approximately $6 \mathrm{mg}$ rice bran starch was placed on a platinum pan. The sample was heated from 30 to $950{ }^{\circ} \mathrm{C}$ at $10{ }^{\circ} \mathrm{C} / \mathrm{min}$ to determine the temperature at which decomposition occurs. During the entire run, air at atmospheric pressure was allowed to flow through the system containing the sample at $20 \mathrm{~mL} / \mathrm{min}$.

\subsubsection{Scanning electron microscopy}

The scanning electron micrographs of rice bran starch were taken with a Cambridge scanning electron microscope (S-360) at an accelerating voltage of $20 \mathrm{kV}$. Starch granules were sprinkled onto a double-sided tape attached to a stub and coated with gold.

\section{Results and discussion}

\subsection{Starch yield and purity}

The wet-milling process for the isolation of rice bran starch shown in Fig. 1 yielded four fractions, viz. starch, protein, course fiber and fine fiber. In this study, rice bran with a starch content of
Table 1

Composition of rice bran starch product.

\begin{tabular}{lc}
\hline Component & \% weight ${ }^{\mathrm{a}}$ \\
\hline Starch & 84.24 \\
Fiber & 5.76 \\
Protein & 0.66 \\
Ash & 9.23 \\
\hline
\end{tabular}

a Dry basis.

about 36\% was utilized. Using the process in Fig. 1, the starch obtained has a purity of $84 \%$ with a corresponding recovery of $83 \%$.

The amylose content of rice bran starch is $5.66 \%$ which characterizes low-amylose rice. The source of rice bran used in this study may have come from a low-amylose variety of rice in Taiwan.

Minor components of the rice bran starch obtained in this study are ash, fiber and protein as shown in Table 1. During starch isolation, it is usually required to remove protein from crude starch obtained. In this study, water and $0.1 \mathrm{M} \mathrm{NaOH}$ were used to wash the crude starch product which resulted in reducing the protein content to $0.66 \%$. The protein in the starch product was difficult to remove because it is not only associated with starch granule surface as in the case of wheat starch (Galliard, 1987) but also bound to the amylose and amylopectin of the starch forming a carbohydrate-protein complex (Chrastil, 1990).

\subsection{Thermal properties}

The thermal decomposition profile of rice bran starch shows three events (Fig. 2). The first thermal decomposition occurred in the temperature interval of $28-131{ }^{\circ} \mathrm{C}$, which corresponds to the dehydration of the starch sample. The second and third events were consecutive and correspond to decomposition in the temperature interval of $210-540^{\circ} \mathrm{C}$. At $302{ }^{\circ} \mathrm{C}$, rice bran starch had a major decomposition that resulted in a mass loss of $45 \%$. Rice bran starch in any application should avoid being subjected to such high temperature to ensure no significant thermal degradation.

As shown in the gelatinization thermogram in Fig. 3, rice bran starch gelatinization is characterized by a broad endothermic peak at $67-78{ }^{\circ} \mathrm{C}$. At this temperature range, irreversible granule swelling, loss of birefringence, and loss of crystallinity occurred after the regions of amorphous starch first melted or undergone glass transition (Bao and Bergman, 2004; Slade and Levine, 1988). The onset and peak gelatinization temperatures for rice bran starch were found at $67{ }^{\circ} \mathrm{C}$ and $73^{\circ} \mathrm{C}$, respectively. The gelatinization enthalpy is about $9.56 \mathrm{~J} / \mathrm{g}$. This heat energy is the amount required

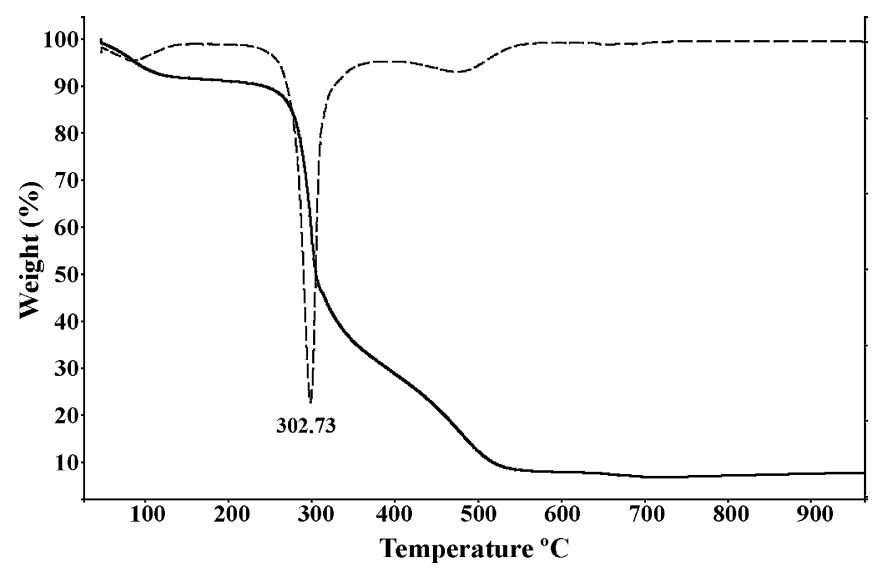

Fig. 2. Thermogravimetric curves of rice bran starch. Weight loss curve (-). Derivative of weight loss (-) 


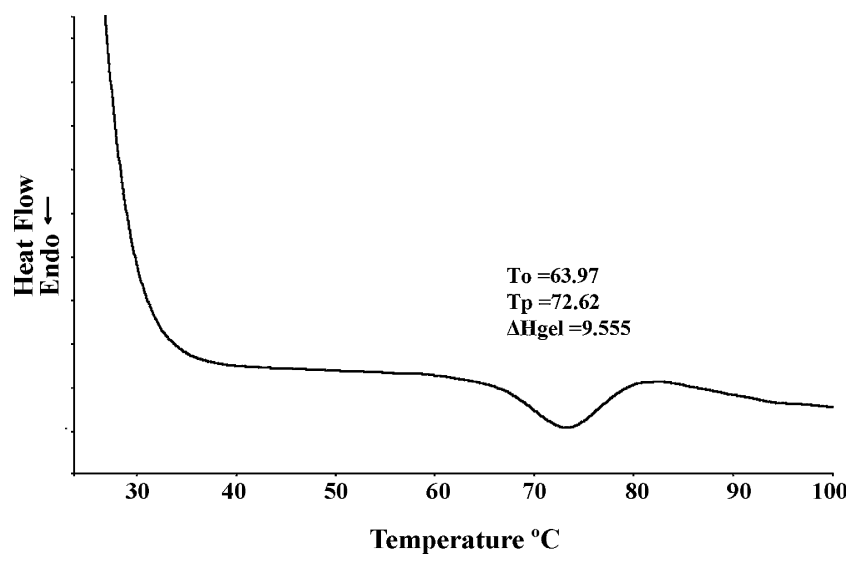

Fig. 3. DSC curve of gelatinization of rice bran starch.

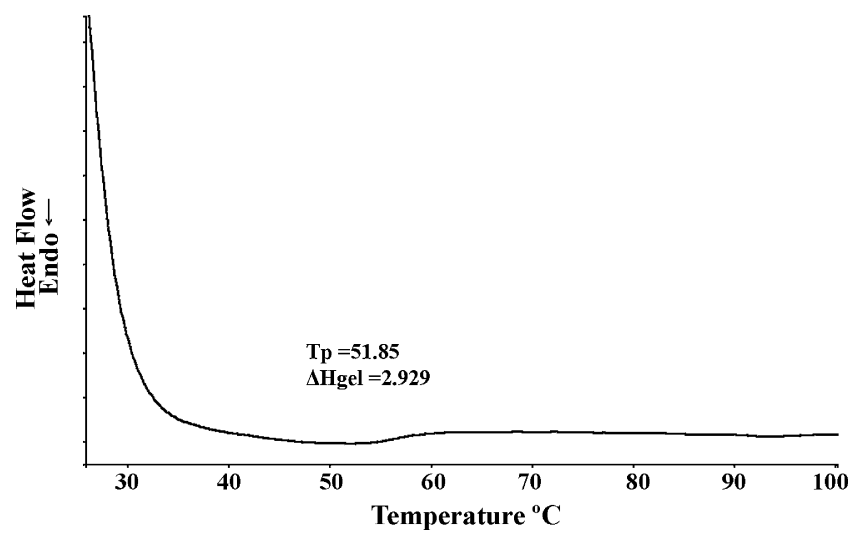

Fig. 4. DSC curve of retrogradation of rice bran starch.

to completely gelatinize starch in rice which is critical to the rice processor, who must optimize heat input, cooking time, and temperature and, at the same time, minimize the cost of the entire process (Bao and Bergman, 2004). Both the transition temperature and enthalpy observed for rice bran starch in the present study were found to agree, within experimental error, with those earlier reports on rice starch (Lii et al., 1995; Russell and Juliano, 1983; Singh Sodhi and Singh, 2003).

The endothermic peaks of starch, after storing the gelatinized rice starch at $4{ }^{\circ} \mathrm{C}$ for 7 days, appeared between 39 and $60{ }^{\circ} \mathrm{C}$ as can be observed in Fig. 4. Retrogradation occurred at about $52{ }^{\circ} \mathrm{C}$ which is lower than the gelatinization temperature of $73{ }^{\circ} \mathrm{C}$. According to Ward et al. (1994), recrystallization of amylopectin branch chains has been reported to occur in a less ordered manner in a stored

Table 2

Thermal properties of rice bran starch.

\begin{tabular}{lll}
\hline Thermal property & $\begin{array}{l}\text { Rice bran } \\
\text { starch }\end{array}$ & $\begin{array}{l}\text { Rice starch (Singh } \\
\text { Sodhi and } \\
\text { Singh, 2003) }\end{array}$ \\
\hline Gelatinization & & \\
Onset temperature, $T_{\mathrm{o}}\left({ }^{\circ} \mathrm{C}\right)$ & 63.97 & 67.26 \\
Peak temperature, $T_{\mathrm{p}}\left({ }^{\circ} \mathrm{C}\right)$ & 72.62 & 71.94 \\
Enthalpy, $\Delta H_{\text {gel }}(\mathrm{J} / \mathrm{g})$ & 9.555 & 11.88 \\
Retrogradation & & \\
Peak temperature $\left({ }^{\circ} \mathrm{C}\right)$ & 51.85 & - \\
Enthalpy, $\Delta H_{\text {ret }}(\mathrm{J} / \mathrm{g})$ & 2.929 & - \\
Retrogradation $(\%)$ & 30.65 & 31.23 \\
Decomposition temperature $\left({ }^{\circ} \mathrm{C}\right)$ & 302.73 & - \\
\hline
\end{tabular}

starch gel than in native starch. This explains the occurrence of amylopectin retrogradation endotherm at a temperature range below that for gelatinization. The enthalpy of retrogradation provides a quantitative measure of energy transformation that occurs during the melting of re-crystallized rice bran starch. The enthalpy needed for the break down of retrograded starch is $31 \%$ of the enthalpy needed to gelatinize the native starch because of the less ordered structure of the re-crystallized starch granules. The thermal properties of rice bran starch obtained in this study and rice starch from previous study are summarized in Table 2 .

(a)
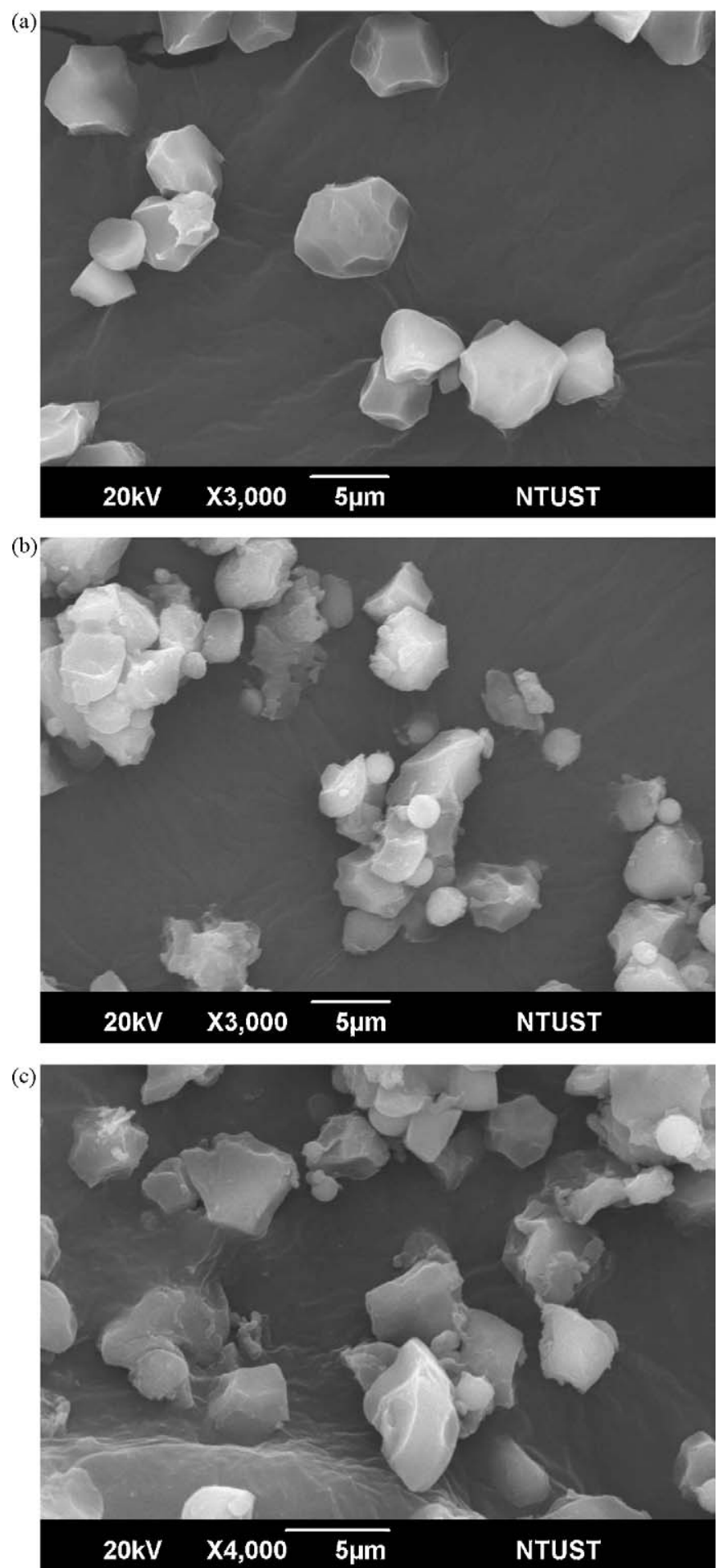

Fig. 5. SEM images of rice flour (a) and rice bran starch (b) (c). 


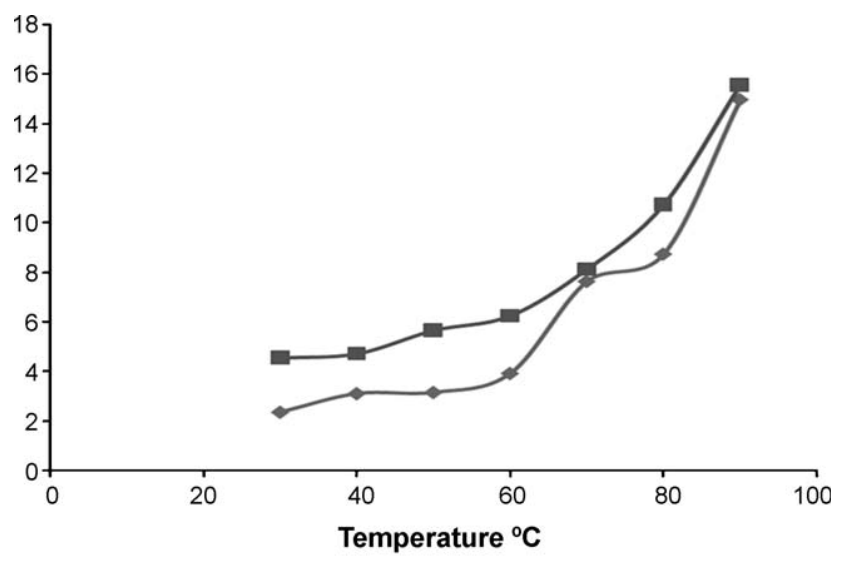

$\rightarrow$ Swelling Power $(\mathrm{g} / \mathrm{g}) \quad \rightarrow-$ Solubility $(\%)$

Fig. 6. Swelling power and solubility of rice bran starch.

\subsection{Morphology of starch}

The scanning electron micrographs in Fig. 5 show the granules in rice flour ( $\sim 90 \%$ starch) and rice bran starch obtained in this study. Rice bran starch is composed of polyhedral granules with sizes of $2-8 \mu \mathrm{m}$. The granules agglomerate and are very similar to the starch granules of rice flour. However, the surfaces of rice bran starch appear to be rougher than that of rice flour. The differences in the appearance of surfaces of the starch granules maybe due to the processing method used. For rice bran starch, alkali treatment was employed while the rice flour was obtained by just subjecting rice kernel to milling.

\subsection{Swelling power and solubility}

According to Leach (1965), the most important property of starch in a commercial application is its ability to swell and produce a viscous paste when heated with water. As shown in Fig. 6, both swelling power and solubility of rice bran starch increase with increasing temperature. The trend for the increase in swelling power and solubility of rice bran starch with temperature reported in this study are similar to the results for starch from low-amylose rice variety (Singh et al., 2000).

In Fig. 6, the swelling power of the starch gradually increased at the temperature range of $25-60{ }^{\circ} \mathrm{C}$ followed by a very sharp increase at $80-90^{\circ} \mathrm{C}$. Leach (1965) reported that for the swelling of cereal flours, two stages occur that reflects the properties of linear and branched polymers. The branched polymer, amylopectin swells to a greater extent along with protein and fat as individual components, but in combination with amylose, a linear polymer, it is more resistant to swelling.

The extent of the solubility of rice bran starch is also shown in Fig. 6. Its solubility increased gradually to $8 \%$ at $70{ }^{\circ} \mathrm{C}$. The increased in solubility become sudden at $70-90{ }^{\circ} \mathrm{C}$ reaching to $15 \%$ solubility of the rice bran starch. Higher solubility was observed for the rice bran starch obtained in this study compared to the rice starch derived from the study of Singh et al. (2000). It is generally well documented that pregelatinized flours or starches will have high solubility although in this study no pregelatinization of starch was done. Probably, higher solubility of rice bran starch can be attributed to the processes it has undergone such as defatting and soaking in water during the extraction procedure.

\section{Conclusions}

Rice bran starch was isolated from defatted rice bran using a wet-milling process. About $83 \%$ of rice bran starch was recovered. The starch product contains $0.66 \%$ protein. The size of starch (2$8 \mu \mathrm{m})$, gelatinization $\left(73^{\circ} \mathrm{C}\right)$ and retrogradation (31\%) properties are within the range reported for rice starch. Thus, rice bran starch maybe used as functional ingredient in food and pharmaceutical industry like starch from rice endosperm as well as find new applications such as a potential material for biomedical applications since it is from a cheap raw material and can compete economically with other cereal starches.

\section{References}

Aman, P. and K. Hesselman, "Analysis of Starch and Other Main Constituents of Cereal Grains,” Swed. J. Agric. Res., 14, 135 (1984).

Bao, J. and C. J. Bergman, "The Functionality of Rice Starch," Starch in Food: Structure, Function and Application, (2004).

Chakraborty, S., B. Sahoo, I. Teraoka, L. M. Miller, and R. A. Gross, "Enzyme-Catalyzed Regioselective Modification of Starch Nanoparticles," Macromolecules, 38, 61 (2004).

Chrastil, J., "Protein-Starch Interactions in Rice Grains. Influence of Storage on Oryzenin and Starch," J. Agric. Food Chem., 38, 1804 (1990).

Dendy, D. A. V. and B. J. Dobraszczyk, Cereals and Cereal Products: Chemistry and Technology, Aspen Publishers, Gaithersburg, MD (2001).

Domb, A. J. N. Manor, and O. Elmalak, "Biodegradable Bone Cement Compositions Based on Acrylate and Epoxide Terminated Poly(Propylene Fumarate) Oligomers and Calcium Salt Compositions," Biomaterials, 17, 411 (1996).

Galliard, T., Starch-Properties and Potential, Published for the Society of Chemical Industry, Wiley, Chichester, England (1987).

Giezen, F. E., R. O. J. Jongboom, H. Feil, K. F. Gotlieb, and D. B. Boersma, "Biopolymer Nanoparticles," U.S. Patent 6, 677, 386B1 (2004).

Helm, R. M. and A. W. Burks, "Hypoallergenicity of Rice Bran Protein," Cereal Food World, 41, 839 (1996).

Ito, M., T. Kato, and T. Matsuda, "Rice Allergenic Proteins, 14-16 kDa Albumin and $\alpha-$ Globulin, Remain Insoluble in Rice Grains Recovered from Rice Miso (Rice-Containing Fermented Soybean Paste)," Biosci. Biotechnol. Biochem., 69, 1137 (2005).

Juliano, B. O., Rice: Chemistry and Technology, American Association of Cereal Chemists, St. Paul, Mimm., USA (1985).

Kaur, L., J. Singh, and Q. Liu, "Starch a Potential Biomaterial for Biomedical Applications," Nanomater. Nanosyst. Biomed. Appl., 83 (2007).

Leach, H. W., "Gelatinization of starch," Whistler, R.L., Paschall, E.F. (Eds.), Academic Press, New York, p. 294, (1965).

Lenaerts, V., I. Moussa, Y. Dumoulin, F. Mebsout, F. Chouinard, P. Szabo, M. A. Mateescu, L. Cartilier, and R. Marchessault, "Cross-linked High Amylose Starch for Controlled Release of Drugs: Recent Advances," J. Control. Release, 53, 225 (1998).

Lii, C. Y., Y. Y. Shao, and K. H. Tseng, "Gelation Mechanism and Rheological Properties of Rice Starch," Cereal Chem., 72, 393 (1995).

Luh, B. S., Rice Production, Van Nostrand Reinhold, New York (1991)

Mano, J. F. and R. L. Reis, "Viscoelastic Monitoring of Starch-Based Biomaterials in Simulated Physiological Conditions," Mater. Sci. Eng. A, 370, 321 (2004).

Matsuda, T. M., N. R. Sugiyama, and S. Torii, "Purification and Properties of an Allergenic Protein in Rice Grain,” Agric. Biol. Chem., 52, 1465 (1988).

Mihara, S., Y. Inaba, K. Tachibana, T. Endo, and E. Yasui, "Process for the Complete Separation of Constituents of Rice Bran and the Like," US. Patent 3, 852,504 (1974).

Pal, K., A. K. Banthia, and D. K. Majumbar, "Starch Based Hydrogel with Potential Biomedical Application as Artificial Skin," Afric. J. Biomed. Res., 9, 23 (2006).

Pereira, C. S., B. Vásquez, A. M. Cunha, R. L. Reis, and J. San Román, "New Starch-Based Thermoplastic Hydrogels for Use as Bone Cements or Drug-Delivery Carriers," J. Mater. Sci. Mater. Med., 9, 825 (1998).

Prosky, L., G. N. Asp, T. F. Scheweizer, J. W. de Vries, and I. Furda, "Determination of Insoluble, Soluble, and Total Dietary Fiber in Foods and Food Products: Interlaboratory Study," J. Assoc. Off. Anal. Chem., 71, 1017 (1988).

Russell, P. L. and B. O. Juliano, "Differential Scanning Calorimetry of Rice Starches," Starch - Starke, 35, 382 (1983).

Sachez-Castillo, C. P., P. J. S. Dewey, J. J. Lara, D. L. Henderson, M. de Lourdes Solano, and W. P. T. James, "The Starch and Sugar Content of some Mexican Cereals, Cereal Products, Pulses, Snack Foods, Fruits and Vegetables," J. Food Comp. Anal., 13, 157 (2000).

Saunders, R. M., "The Properties of Rice Bran as a Food Stuff," Cereal Food World, 35, 632 (1990).

Shelton, D. R. and W. J. Lee, “Cereal Carbohydrates,” Kulp, K., Ponte, J.J.G. (Eds.), Marcel Dekker Inc., New York, p. 385 (2000).

Singh Sodhi, N. and N. Singh, "Morphological, Thermal and Rheological Properties of Starches Separated from Rice Cultivars Grown in India," Food Chem., 80, 99 (2003).

Singh, V., H. Okadome, H. Toyoshima, S. Isobe, and K. Ohtsubo, "Thermal and Physicochemical Properties of Rice Grain, Flour and Starch," J. Agric. Food Chem. 48, 2639 (2000)

Slade, L. and H. Levine, "Non-Equilibrium Melting of Native Granular Starch: Part I. Temperature Location of the Glass Transition Associated with Gelatinization of AType Cereal Starches," Carbohydr. Polym., 8, 183 (1988). 
Ward, K. E. J., R. C. Hoseney, and P. A. Seib, "Retrogradation of Amylopectin from Maize and Wheat Starches," Cereal Chem., 71, 150 (1994).

Watanabe, M., J. Miyakawa, Z. Ikezawa, Y. Suzuki, T. Hirao, T. Yoshizawa, and S. Arai, "Production of Hypoallergenic Rice by Enzymatic Decomposition of Constituent Proteins," J. Food Sci., 55, 781 (1990).
White, P. J., I. R. Abbas, and L. A. Johnson, "Freeze-Thaw Stability and RefrigeratedStorage Retrogradation of Starch," Starch - Starke, 41, 176 (1989).

Won, C. Y., C. C. Chu, and T. J. Yu, "Synthesis of Starch-Based Drug Carrier for the Control/Release of Estrone Hormone," Carbohydr. Polym., 32, 239 (1996). 